\title{
PELAKSANAAN SUPERVISI AKADEMIK \\ KEPALAMADRASAH DALAM MENINGKATKAN KINERJA PENDIDIK DI MADRASAH ALIYAH WALISONGO
}

\author{
Wismoyo Sandi Nugroho \\ Unversitas Islam Negeri Raden Intan Lampung \\ E-mail: Sandinugrohowismoyo@gmail.com
}

\begin{tabular}{|c|c|c|}
\hline Received & Revised & Accepted \\
\hline 10 Januari 2021 & 10 Februari 2021 & 28 Maret 2021 \\
\hline
\end{tabular}

\section{IMPLEMENTATION OF ACADEMIC SUPERVISION OF HEADMASTER TO IMPROVE THE TEACHER PERFORMANCE AT MADRASAH ALIYAH WALISONGO}

\begin{abstract}
This study discusses the implementation of supervision carried out by the head of the Salam madrasa in order to improve the performance of educators at Madrasah Aliyah Walisongo. The results of this study are the implementation of the academic supervision of the madrasah principal in the planning stage is quite good. It's just that in the implementation activities as well as the evaluation or follow-up has not been carried out properly and optimally. Therefore, there should be activities that lead to an increase in the implementation of the academic supervision of the madrasah principal. As well as teaching performance for educators should always be improved continuously, which is done gradually both in planning, implementation and evaluation. The head of the madrasa should have strong self-guidance in determining all decisions in dealing with problems related to educators in order to improve the performance of educators so that there is an increase. Madrasah principals should be more selective or selective in recruiting new educators to be hired.
\end{abstract}

Keywords: implementation, academic supervision, and headmaster.

\begin{abstract}
Abtrak
Penelitian ini membahas mengenai pelaksanaan supervisi yang dilakukan oleh kepala madrasah salam rangka untuk meningkatkan kinerja pendidik di Madrasah Aliyah Walisongo. Hasil penelitian ini adalah Penerapan supervisi akademik kepala madrasah di dalam tahapan perencanaan sudah cukup baik. Hanya saja di dalam kegiatan pelaksanaanya maupun evaluasinya atau tindak lanjutnya belum dilakukan dengan baik dan maksimal. Maka dari itu, hendaknya ada kegiatan yang menuju kearah peningkatan dalam penerapan supervisi akademik kepala madrasahnya. Serta kinerja pengajaran bagi para pendidik
\end{abstract}


hendaknya senantiasa di tingkatkan terus, yang dilakukan dengan terus berangsur angsur baik dalam perencanaan, pelaksanaan dan evaluasinya. Kepala madrasah hendaknya mempunyai pedoman diri yang kuat didalam menentukan segala keputusan dalam menghadapai permasalahan terkait pendidik guna memperbaiki kinerja dari pendidik supaya terjadi peningkatan. Kepala madrasah hendaknya lebih pilih pilih atau selektif dalam merekrut para dewan pendidik baru yang akan dipekerjakan.

Kata kunci: pelaksanaan, supervisi akademik, dan kepala sekolah.

\section{Pendahuluan}

Kepala madrasah merupakan pendidik yang memiliki jabatan tertinggi disuatu lembaga, ia adalah pendidik yang diberikan tanggung jawab tambahan dalam memimpin madrasahnya. Dan seorang pemimpinhendaknya mempunyai ciri khas khusus yakni meliputi kepribadian karakter yang baik, keahlian khususdan bersifat professional dalam amanahnya, serta memiliki pengalaman dan pengetahuan yang luas terhadap ilmu administrasi, dan kemampuan pengawasan. Seorang kepala madrasah adalah seorang yang berperan penting untuk membawa sebuah lembaga tersebut maju kedepanya dan mundur sebaliknya. ${ }^{1}$

Kepala madrasah disini merupakan sisi profesi tertinggi di lingkungan madrasah dan memiliki bebansebagai penangung jawabterbesar bagikomponen komponen yang ia pimpin di madrasah. Dan salah satunya, ialah memberikan bimbingan bimbingan dan pengaruh positif kepada yang ia pimpin di lingkungan tempat madrasah tersebut. sehingga, seorang kepalamadrasah disini harus memiliki kemampuankompetensi khususdalam memimpin madrasah secara umum ataukeseluruhan.

Selain itu, yang paling utama dari kepala madrasah, adalah sebagai pengawas dan penanggung jawab madrasah yang dia pimpin.Dia mengawasi seluruh program madrasah yang terprogram dan menanggungtanggung jawab utama untuk kinerja yang ada. ${ }^{2}$

Pada lingkup dunia pendidikan,khususnya di madrasah, yang berperan sebagai pengawas atau supervisor ialah kepala madrasah yang berada dimadrasah.Dalam prakteknya, seorang supervisor yakni kepala madrasah hendaknyamementingkan prinsip prinsip pelaksanaanya : (1) menjalin kerjasama konsultatif, kolegial dan bukan hirarkis (2) dilakukan dan diterapkan secara demokratis (3) intinya pada tenaga kependidikan (4) dilaksanakan berdasarkan pada kebutuhan kependikan (5) merupakan pemberian bantuan yangberkwalitas. Dari hal tersebut adalah point point penting dalam mecapai kesuksesan tujuan dari supervisi kepala madrasah.

Peranan kepala madrasah sebagai seorang supervisor sangatlah penting sekali, karena supervisi sendiri ialah suatu kegiatan pengawasan dari kepala madrasah untuk membenahi kondisi internal maupunexternal dan yang berhubungan dengan fisik dan non fisik dari suatu lembaga pendidikan untuk mencapai suatu proses pembelajaran yang menjadi lebih baik. Maka dari itu, dalam penelitian ini, peneliti fokus pada pelaksanaan supervisi akademik kepala madrasah dalam meningkatkan

\footnotetext{
${ }^{1}$ E. Mulyasa, Menjadi Kepala Sekolah Profesional (Bandung: Remaja Rosdakarya, 2005), h. 115.

${ }^{2}$ Saqib Khan et al., "The Supervisory Role of the The Supervisory Role of the Headmaster at the Higher Secondary Level: A Teacher's Perception," Public Policy and Administration Research 4, no. 9 (2014): 51-55, h. 51.
} 
kinerja pendidik. Karena supervisi akademik, adalah suatu cara atau aturan untuk memberikan arahan kepada pendidik untuk memperbaiki kinerjanya dalam kegiatan belajar mengajar ke arah yang lebih baik. Mengingat kepala madrasah, mempunyai peranan yang sangat strategis sebagai supervisor maka ia adalah orang yang bertanggung jawab terhadap kesuksesan dan kemajuan madrasah yang dipimpinya.Oleh karenanya, kepala madrasah harus berperan sebagai supervisor, yang menciptakan kematangan, dan profesionalisme pendidik. ${ }^{3}$ Dengan kata lain, dengan dilaksanakanya program supervisi akademik, bertujuan untuk memberikan layanan bimbingan akademik terhadap peningkatan kinerja pengajaran.

Terlebih lagi, dalam proses supervisi kepala madrasah menyatakan bahwa, terdapat indikator yang jelas dalam penerapan dan pelaksanaanyayang telah diatur didalam Undang Undang Permendiknas No. 13 tahun 2007, yaitu:

1) Mencanangkanprogram supervisi akademik terhadap peningkatan profesionalisme pendidik.

2) Melaksanakan supervisi akademik terhadap para pendidik menggunakan pendekatan dan metode atau teknik supervisi yang tepat dan sesuai.

3) Menindak lanjuti hasil supervisi akademik terhadap para pendidik dalam meningkatan profesionalisme pendidik.

Dari ketiga indikator supervisi tersebut, adalah suatu acuan yang paling penting dalam aktifitas supervisi dan kegiatan supervisi yang dilakukan kepala madrasah merupakan aspek yang sangat menunjang kinerja pendidik di madrasah.Terdapat banyaksekali penelitian penelitian yang membahas tentang supervisi akademik kepala madrasah di madrasah madrasah yang ada dalam meningkatkan kualitas pendidikan di madrasah. Salah satu penelitian supervisi ialah jurnal yang berjudul "Implementasi supervisi pendidikan dalam meningkatkan proses pembelajaran di MIN Sukadamai Kota Banda Aceh" karya Cut Suryani dari program Pascasarjana UIN Ar-Rainiry Banda Aceh. ${ }^{4}$

Berdasarkan penelitian yang telah dilaksanakan oleh peneliti, terkait pelaksanaan supervisi dapat diambil benang merah bahwa perencanaan supervisi yang dipersiapkan dan disusun diawal dan dibina programnya secara jelas berpengaruh terhadap pelaksanaan yang dilakukan, beberapa pelaksanaan pembinaan supervisi pendidikan yang dilakukan oleh kepalamadrasah meliputi penyusunan program tahunan, kunjungan supervisi ke kelas, dan laporan hasil tindak lanjut dari penelitian. Selain itu juga, melakukan pembinaan supervisi terhadap semua komponen pendidikan di madrasah.Pelaksanaan yang dilakukan oleh kepala madrasah, menekankan pada pembinaan terhadap kemampuan pendidik dalam mengelola pembelajaran, dan hal ini, sangatlah membantu dan memotivasi pendidik agar selalu meningkatkan pengetahuan untuk menjadi pendidik yang professional dalam kinerja pengajaran. Terlebih lagi, pelaksanaan pembinaan supervisi akademik yang dilakukan, menciptakan suasana peningkatan yang lebih baik terhadap kinerja para pendidik dalam proses pembelajaran, hal ini dibuktikan dengan pembinaaan

\footnotetext{
${ }^{3}$ Jerry H Makawimang, Supervisi Klinis (Teori \& Pengukuranya) (Bandung: Alfabeta, 2013), h.52.

${ }^{4}$ Pascasarjana Program, Ar-Raniry Uin, And Aceh Banda, "Implementasi Supervisi Pendidikan Dalam Meningkatkan Proses Pembelajaran Di Min Sukadamai Kota Banda Aceh Cut Suryani," Jurnal Ilmiah Didaktika Agustus, Vol. 16, 2015, h. 19.
} 
kemampuan para pendidik yang dilakukan secara efektif dan efisien.Salah satunya, adalah peningkatan bekal pengetahuan pada para pendidikdengan mengirim para pendidik dalam kegiatan kegiatan yang bersifat menambah ilmu ilmiah seperti penataran, pelatihan dan diskusi sesama para dewan pendidik guna meningkatkan kompetensi dan sebagai evaluasi dan tindak lanjut dalam menyelesaikan bersama masalah masalah yang sedang dihadapi oleh para pendidik agar kedepanya menjadi lebih baik.

Dari penelitian tersebut, membuktikan bahwa,pelaksanaan supervisi akademikmelalui pembinaan yang dilakukan oleh kepala madrasah, sangatlah penting, dan sangat efektifdalam meningkatkan kinerja para pendidik. Peneliti mengambil penelitian tentang "pelaksanaan supervisi akademik kepala madrasah dalam meningkatkan kinerja pendidik di Madrasah Aliyah Umbul Madiun”.

Pada penelitianya, difokuskan pada pelaksanaan supervisi akademik kepala madrasah dalam meningkatkan kinerja pendidik di Madrasah Walisongo Umbul Madiun. Berdasrkandata observasi awal supervisi akademik yang telah dilaksanakan telah melalui tiga tahapan. Sesuai dengan indikator pelaksanaan supervisi yang telah ditentukan, tahap indikator tersebut ialah : perencanaan, pelaksanaan dan evaluasi atau tindak lanjut dari supervisi akademik.

Dapat diketahui bahwasanya, perencanaan yang telah dilaksanakan di Madrasah Aliyah Walisongo sudah dilaksanakan dengan baik seperti rapat musyawarah awal semester yang dikuti semua pendidik dan staff, perencanaan program bersama satu tahun kedepan, perencanaan program supervisi dan musyawarah terkait visi misi madrasah kedepanya semua sudah dilakukan.

Dari berbagai hal di atas, menunjukan bahwa pelaksanaan supervisi akademik kepala madrasah sudah terlaksana dengan baik dalam perencanan programnya, dan dalam pelaksanaan supervisinya masih terlaksana sebagian atau masih setengah setengah namun, untuk evaluasi atau tindak lanjutnya sendiri masih belum terlaksana. Dalam perjalananya pelaksanaan dan evaluasi atau tindak lanjutnya, sebenarnya harus dilakukan dengan baik karena berefek pada kelangsungan majunya madrasah dari sisi kinerja dalam kegiatan belajar mengajar.Dikarenakan, tujuan dari program supervisi akademik sendiri, ialah memberikan bimbingan kepada para pendidik dalam meningkatkan kualitas kinerja mengajar sehingga diharapkan memberikan dampak yang baik bagi kualitas pengajaran serta sebagai ujung tombak atau pemain inti proses pendidikan. Kualitas kinerja dari seorang pendidik, nantinya yangakanmenentukan kualitas mutu serta output lulusan peserta didik yang dihasilkankedepanya. Maka dari itu makna kinerja pendidik disini memiliki arti yang sangat penting.

Kinerja pendidik sendiri, adalahskill of work atau kemampuan pembuktian kerja yang ditunjukanoleh seseorang pendidik dalam proses memperoleh hasil pekerjaan yang memuaskan dalam kegiatan belajar mengajar. Karena suksesnya kinerja seorang pendidik, dalam menjalankan amanah pekerjaanya, bisa dilihat dari ketulusanya dalam memberikan pengajaran kepada peserta didik, tanggung jawab secara profesional terhadap amanah dan profesinya, serta hendaknya harus tertanammoral yang baik pada dirinya karena pendidik adalah seseorang yang bisa 
digugu dan ditiru. Maka, seorang pendidik hendaknya memenuhi kompetensi kinerja yang baik dalam menjalankan tugasnya. ${ }^{5}$

Untuk mengetahui masalah yang ada peneliti sendiri telah melakukan pra penelitian terlebih dahulu.dari hasil data yang diperoleh melalui kegiatan wawancara intens dengan kepala madrasah dan berdasarkan dokumen madrasah. Hasil supervisi yang telah dilaksanakan kepala madrasah pada tanggal 2 Februari 2019 yaitu belum maksimal dan kinerja pendidik dan staff masih perlu diadakan perbaikan Hal ini dibuktikan ketika kepala madrasah melakukan supervisi secara langsung mengunjungi kelas. Kebanyakan dari para pendidik belum menggunakan teknik pembelajaran yang modern dan yang menyenangkan serta sesuai dengan mata pelajaran yang diampu karena didapati masih banyak yang menggunakan teknik pengajaran yang terbilang jadul.Memperhatikan dengan masalah yang ada, kepala madrasah mengadakan kegiatan tindak lanjut dengan mengadakan pelatihan pelatihan dengan pokok pengajaran mengenai modernisasi teknik pengajaran yang dibimbing kepala madrasah. ${ }^{6}$

Dari sisi mencontohkan hal yang baik dalam menjalankan kinerja sebagai sebagai seorang pemimpin dimadrasahnya, kepala madrasah sudah melakukanya tetapi, contoh tersebut belum juga merubah kinerja pendidik supaya lebih baik danmemuaskan, dari jumlah pendidik beserta staff yang adadiketahui dari data terkhir yang didapat sebanyak dua puluh enam pendidik, dan diketahui ada beberapa masalah atau problem yang ditemukan terkait kinerja mengajar pendidik di Madrasah Aliyah Walisongo Umbul Madiun antara lain yakni : terdapat 15 pendidik dari keseluruhan dua puluh enam pendidikyang menggunakan perangkat silabus pengajaran dalam pembelajaranyayang sudah menggunakanya.Masalah yang selanjutnya, adalah perangkat pembelajaran yang digunakan atau rencana perangkat pembelajaran, dalam pembuatan rencana perangkat pembelajaranini hanya 14 orang saja yang membuat rencana perangkat pembelajaran sedangkan sisanya, pendidik yang lain tidak membuatrencana perangkat pembelajran.dari temuan ini menggambarkan bahwa beberapa pendidik belum tertib dalam melengkapi administrasi pembelajaran.Hal ini tentunya menggambarkan bahwa kinerja pendidik dalamperencanaan awal pembelajaran masih belum baik. Masalah yang selanjutnya, adalah mengenai penggunaan teknik pengajaran dalam menyampaiakan materi pembelajaran yang tepat sesuai mata pelajaran yang diampu. Dari hasil pra penelitian diketahui bahwa,hanya ada 18 orang pendidik saja yang menggunakan teknik pengajaran yang sudah tepat dengan mata pelajaran yang diampu, selain itu pendidik yang lainya masih menggunakan metode seperti ceramah satu arah atau bisa dibilang metode lama yang membosankan, selain itu ada juga yang menggunakan metode dikte menulis yang itu terbilang sangat membosankan bagi peserta didik karena peserta didik hanya disuruh menulis namun tidak diberikan penjelaaan lengkap tentang apa yang mereka tulis. Masalah yang selanjutnya lagi, adalah pendidik dalam mengevaluasi dan menindaklanjuti pembelajaran yang telah

\footnotetext{
${ }^{5}$ H Makawimang Jerry, Supervisi Klinis : Teori \& Pengukuranya (Bandung: Alfabeta, 2012), h.54.

${ }^{6}$ Komari, Kepala Madrasah Aliyah Walisongo Umbul Madiun, Wawancara, Tanggal 2 Februari 2019.
} 
dilakukanya.Didapati bahwa, hanya ada 17 pendidik saja yang melakukan evaluasi pembelajaran kembali setelah melakukan pengajaran sedangkan yang lain tidak. Diketahui juga, hanya ada 11 orang pendidik yang tidak aktif dalam ketertiban absensi harian pendidik madrasah seperti pengisian daftar hadir dikelas yang ia ajar dan ketelatenan mengabsensi peserta didiknya sebelum diawali pembelajaran.

Dari keterangan data tersebut, bisa disimpulkan sementara bahwa, kinerja pendidik dalam proses pegajaran masih rendah dan belum termaksimalkan di Madrasah Aliyah Walisongo Umbul Madiun maka dari itu perlu diteliti lebih mendalam.

Bersadarkan latarblakang di atas, fokus dari penelitian iniadalah untuk menelitipelaksanaansupervisi akademik kepala madrasah dalam meningkatakan kinerja pendidik di Madrasah Aliyah Walisongo Umbul Madiun.

\section{Metode Penelitian}

Jenis penelitian ini adalah penelitian lapangan (field research) yaitu penelitian yang meneliti fakta fakta dan permasalahan yang ada dilapangan. Sedangkan sifat penelitian ini termasuk penelitian deskriptif kualitatif, yaitu penelitian yang menggambarkan kondisi lapangan apa adanya di Madrasah Aliyah Walisongo Umbul Madiun.

Metode pengumpulan data pada penelitian ini dengan cara dokumentasi, observasi dan wawancara langsung di lokasi penelitian, yakni di Madrasah Aliyah Walisongo Umbul Madiun.Dalam hal mengelolahan data, penulis menggunakan metode secara kualitatif.

Analisis dalam penelitian dilakukan pada saat pengumpulan data berlangsung dan setelah selesai pengumpulan data dalam periode tertentu pada saat wawancara, peneliti sudah melakukan analisis terhadap jawaban yang diwawancarai. Bila jawaban yang diwawancarai setelah dianalisis terasa belum memuaskan, maka penelitiakan melanjutkan pertanyaan lagi, sampai tahap tertentu, diperoleh data yang dianggap kredibel.

\section{Hasil dan Pembahasan \\ Supervisi Pendidikan}

\section{Pengertian Supervisi Akademik}

Supervisi Akademik yaitu yang menitikberatkan pada pengamatan supervisor pada masalah masalah akademik, yaitu hal hal yang langsung berada dalam lingkungan kegiatan pembelajaran pada waktu peserta didik sedang dalam proses pembelajaran. ${ }^{7}$ Selain itu, supervisi akademik adalah serangkaian kegiatan pembinaan yang membantu pendidik dalam meningkatkan kualitas mengajarnya yang berimplikasi pada meningkatnya hasil belajar peserta didik.

Supervisi akademik, berpusat pada masalah pembelajaran peserta didik. Supervisi ini dilakukan kepala madrasah untuk mengetahui kemampuan mengajar pendidik yang kemudian akan diberikan bimbingan sehingga poin dari supervisi akademik adalah bukan untuk menilai performa pendidik akan tetapi, memberikan

\footnotetext{
${ }^{7}$ Suhardan, Supervisi Profesional(Bandung : Alfabeta), h. 47..
} 
bimbingan kepada pendidik. Terlebih lagi, secara general supervisi dapat dimaknai atas dasar keseluruhan aktifitasnya yang dilakukan secara individu maupun kelompok sesuai dengan tujuan masing masing terhadap personel, kelompok ataupun terhadap suatu program dalam berbagai bidang kependidikan. Adapun rangkaina kegiatan supervisi pendidikan dapat dikelompokan dalam empat tahap kegiatan yakni sebagai berikut ${ }^{8}$ :

1. Penilaian terhadap keadaan pendidik/orang yang di supervisi dalam menjalankan tugas tugasnya.

2. Penilain (evaluation) yakni, penafsiran tentang keadaan pendidik atau orang yang disupervisi, baik mengenai kekurangan atau kelemahan kelemahanya, berdasarkan dengan data penelitian.

3. Perbaikan (improvement) yakni, memberikan bimbingan dan petunjuk untuk mengatasi kekurangan atau kelemahan pendidik, serta mendorong pengembangan kebaikan kebaikan atau kebihan disetiap pendidik yang di supervise.

4. Pembinaan yakni, kegiatan menumbuhkan sikap yang positif pada pendidik atau orang yang di supervisi agar mampu menilai diri sendiri dan berusaha memperbaiki atau mengembangkan diri kearah terbentuknya keterampilan dan penugasan ilmu pengetahuan yang selalu up to date, actual dan sesuai dengan tuntunan masyarakat dan arus globalisasi. ${ }^{9}$ Menurut Alfonso Da Neville, ada tiga konsep pokok dalam pengertian supervisi akademik, yaitu :

a. Supervisi akademik harus secara langsung mempengaruhi dan mengembangkan perilaku pendidik dalam mengelola proses pembelajaran.

b. Perilaku supervisor dalam membantu pendidik mengembangkan kemampuanya harus di desain secara professional, sehingga jelas waktu mulai dan berakhirnya program pengembangan tersebut.

c. Tujuan akhir supervisi akademik adalah agar pendidik semakin mampu memfasilitasi belajar bagi peserta didiknya. ${ }^{10}$

Supervisi akademik merupakan bantuan professional yang diberikan oleh kepala madrasah melalui tiga tahapan yakni penilaian, perbaikan, dan pembinaan.Tugas kepala madrasah sebagai supervisor adalah mensupervisi bawahanya, baik itu staf TU, dan lainya.Supervisi akademik tentunya berkaitan dengan kepala madrasah yang mensupervisi segala kegiatan pembelajaran.Dari kosep diatas, memberikan arahan bahwa kegiatan supervisi akademik harus terukur baik waktu dan pengaruhnya terhadap perilaku pendidik, sehingga pendidik mampu memfasilitasi belajar bagi para peserta didik.

\footnotetext{
${ }^{8}$ Hadari Nawawi, Administrasi Pendidikan (Jakarta: CV Haji Mas Agung, 1998), h. 112 - 113.

${ }^{9}$ Ibid.

${ }^{10}$ Direktorat Tenaga Kependidikan Direktorat Jenderal Penjamin Mutu Pendidikan dan Tenaga Kependidikan Departemen Pendidikan Nasional Tim Penulis, Metode Dan Tehnik Supervisi (Jakarta: Diknas, 2008), h. 10.
} 


\section{Tujuan Supervisi Akademik Pendidikan}

Secara umum, tujuan supervisi akademik adalah membantu pendidik untuk mengembangkan kemampunanya dalam mencapai tujun pembelajaran yang direncanakan bagi peserta didiknya. Melalui supervisi akademik diharapkan kualitas akademik yang dilakukan oleh pendidik semakin meningkat.Pengembangan kemampuan pendidik tidak hanya menyangkut pada peningkatan pengetahuan dan keterampilan mengajar pendidik saja, namun juga meliputi peningkatan komitmen (commitment), kemauan (willingsness) dan motivasi (moivation) pendidik, kualitas pembelajaran akan semakin meningkat.

Panduan supervisi akademik Dirjen PMPTK 2o1odinyatakan bahwa, tujuan supervisi akademik adalah :

a. Membantu Pendidik Mengembangkan Kompetensi Pengajaran

Supervisi akademik diselenggarakan dengan maksud membantu pendidik mengembangkan kemampuan profesionalnya dalam memahami akademik, kehidupan kelas, mengembangkan keterampilan mengajarnya, dan mengembangkan kemampuanya melalui teknik teknik tertentu.

b. Mengembangkan Kurikulum

Supervisi akademik diselenggarakan dengan maksud untuk memonitor kegiatan belajar mengajar di madrasah, kegiatan memonitor ini bisa dilakukan melalui kunjungan kepala madrasah ke kelas kelas disaat pendidik sedang mengajar, percakapan pribadi dengan pendidik, teman sejawatnya, maupun dengan sebagian peserta didiknya.

c. Mengembangkan kelompok kerja pendidik serta membimbing penelitian tindakan kelas (PTK).

Supervisi akademik diselenggarakan untuk mendorong pendidik menerapkan kemampuanya dalam melaksanakan tugas tugas mengajarnya,mendorong pendidik mengembangkan kemampuanya sendiri, serta mendorong pendidik agar ia memiliki perhatian yang sungguh sungguh terhadap tugas dan tanggung jawabnya.

Dari beberapa pengertian tentang supervisi akademik tersebut, maka dapat difahamibahwa, supervisi akademik mempunyai tujuan untuk mengembangkan profesionalisme pendidik dan memberikan motivasi kepada pendidik untuk selalu melakukan perbaikan dalam kinerja. Tujuan supervisi ialah bantuan bukan sebuah inspeksi, sehingga kepala madrasah dapat melakukan program supervisi dengan baik agar tujuan supervisi akademik dapat tercapai.

\section{Prinsip Supervisi Supervisi Akademik}

Kepala madrasah sebagai supervisor dalam melaksanakan harus memperhatikan prinsip prinsip supervisi agar dalam pelaksanaan supervisi dapat berjalan dengan baik dan lancar. Prinsip itu antara lain :

a. Prinsip Ilmiah

Perinsip ilmiah mengandung ciri ciri sebagai berikut :

1) Kegiatan supervisi dilaksanakan berdasarkan data obyektif yang diperoleh dalam kenyataan pelaksanaan proses belajar mengajar.

2) Untuk memperoleh data perlu diterapkan alat perekam data seperti angket, observasi, percakapan pribadi, dan seterusnya. 
3) Setiap kegiatan supervisi dilaksanakan secara sistematis terencana.

b. Prinsip Demokratis

Servis dan bantuan yang diberikan kepada pendidik berdasarkan hubungan kemanusiaan yang akrab, dan kehangatan sehingga pendidik merasa aman untuk mengemban tugasnya. Demokratis mengandung makna menjunjung tinggi harga diri dan harkat martabat pendidik, bukan berdasarkan atasan dan bawahan. ${ }^{11}$

c. Prinsip Kerjasama

Mengembangkan usaha bersama atau menurut istilah supervisi " sharing of idea, sharing of experience " memberi support mendorong, menstimulasi pendidik, sehingga merasa tumbuh bersama.

d. Prinsip Konstruktif dan Kreatif

Setiap pendidik akan merasa termotivasi dalam mengembangkan potensi kreativitas dalam supervisi mampu menciptakan suasana kerja yang menyenangkan, bukan melalui cara cara yang menakutkan. ${ }^{12}$

Dari uraian diatas dapat kita ketahui, bahwa betapa banyak dan besarnya tanggung jawab seorang kepala madrasah sebagai supervisor.

Dalam pelaksanaan supervisi, terdapat prinsip prinsip yang harus dipenuhi dalam program supervisi. Prinsip yang harus dipenuhi ialah demokratis yang artinya semua pendidik berhak menyatakan pendapatnya dalam penyusunan program supervisi. Prinsip kerjasama juga harus dipenuhi karena tanpa kerjasama yang baik maka program tersebut tidak akan berjalan sesuai dengan yang diharapkan.

Dalam teori lain juga menyebutkan tentang prinsip yang harus dipenuhi dalam program supervisi. Pelaksanaan supervisi akademik perlu mengacu pada prinsip prinsip yang ada dalam supervisi akademik.

\section{Fungsi Supervisi Akademik}

Fungsi utama supervisi adalah ditunjukan pada perbaikan dan peningkatan kualitas, agar sasaran supervisi terlaksana dalam peningkatan kinerjasecara efektif, maka kemampuan pendidik perlu ditingkatkan, maka fungsi supervisi menurut Amatembun terdiri dari :

a. Penelitian

Yaitu fungsi supervisi yang harus dapat mencari jalan keluar dari masalah yang dihadapi.

b. Penilaian

Fungsi penilaian adalah untuk mengukur tingkat kemajuan yang diinginkan, seberapa besar yang telah dicapai, dan penilain ini dilakukan dengan berbagai cara seperti tes, penetapan standar, penilaian kemajuan belajar peserta didik, melihat perkembangan hasil penilaian madrasah, serta prosedur lain yang berorientasi pada peningkatan mutu pendidikan.

c. Perbaikan

\footnotetext{
${ }^{11}$ Sahertian, Konsep Dasar Dan Tehnik Supervisi Pendidikan Dalam Rangka Mengembangkan SDM, (Jakarta: Rineka Cipta, 2010), h. 19.

${ }^{12}$ Ibid.
} 
Fungsi perbaikan, adalah sebagai usaha untuk mendorong pendidik baik secara perseorangan maupun kelompok agar mereka mau melakukan berbagai perbaikan dalam menjalankan tugas mereka. Perbaikan ini dapat dilakukan dengan bimbingan, yaitu dengan cara membangkitkan kemauan, memberi semangat, mengarahkan dan merangsang untuk melakukan percobaan, serta membantu menerapkan sebuah prosedur mengajar yang baru.

\section{d. Pembinaan}

Fungsi pembinaan merupakan salah satu usaha untuk memecahkan masalah yang sedang dihadapi, yaitu dengan melakukan pembinaan atau pelatihan kepada para pendidik tentang cara cara baru dalam melaksanakan suatu proses pembelajaran, pembinaan ini dapat dilakukan dengan cara demonstrasi mengajar, workshop, seminar, observasi, konfrensi individual atau kelompok, serta kunjungan supervisi. ${ }^{13}$

\section{Pencanangan Program Supervisi Akademik}

Aktifitas supervisi yang dilaksanakan oleh kepala madrasah merupakan kegiatan yang memiliki tiga indikator pencapaian dalam supervisi pendidikan, yaitu perencanaan program supervisi, pelaksanaan program supervisi, dan manfaat dari hasil kegiatan supervisi.Supervisi yang sudah dilaksanakan di Madrasah AliyahUmbul Madiunmemiliki harapan untuk berhasil membantu tenaga pendidik untuk meningkatakan kualitas kemampuanya dalam pengajaran dikemudian hari.

Berdasarkan hasil yang didapat dari wawancara intens bersama kepala madrasah, kegiatan perencanaan programnya dibuat dengan para dewan pendidik dan staf tata usaha. Kepala madrasah mengadakan rapat agenda awal tahun yang diikuti semua perangkat madrasah seperti para pendidik, operator, dan staff tata usaha .hal ini dibuktikan dengan adanya buku daftar hadir musyawarah yang ditandatangani oleh seluruh perangkat madrasah. Tentunya ini menunjukan bahwa semua pendidik mengikuti musyawarah awal tahunan tersebut.Hal ini dibuktikan dengan hasil wawancara intens dengan ibu wakil kepala bidang kurikulum madrasah yakni ibu Chamidah beliau mengatakan bahwa,"agenda rapat sudah dilaksanakan dan semua dewan pendidik hadir pada saat itu guna membahas perencanaan madrasah pada satu tahun kedepan".

Dalam musyawarah awal tahun tersebut membahas kegiatan program madrasah yang meliputi kegiatan aktifitas program peserta didik, program peningkatan profesionalitas pendidik, program peningkatan prestasi belajar para peserta didik, serta program evaluasi kegiatan. Kepala madrasah sebagai pimpinan melakukan pengecekan kembali terkait program yang dicanangkan pada satu tahun kedepan.Program yang dicanangkan berhubungan dengan pencapaian tujuan madrasah.Hal tersebut dibuktikan dengan adanya dokumntasi program program madrasah yang dicanangkan.Semua program itu dirangkum di dalam buku besar agenda musyawarah awal tahunan Madrasahyang ditulis oleh notelen rapat.

Di dalam menentukan program madrasah, seorang kepala madrasah bukan hanya melibatkan perangkat madrasah seperti dewan pendidik dan staff saja

\footnotetext{
${ }^{13}$ Maryono, Dasar Dasar Tehnik Menjadi Supervisi Pendidikan, h. 23.
} 
melainkan kepala madrasah juga melibatkan perwakilan dari peserta didik yakni para pengurus OSIS dan Pradana dalam merencanakan kegiatan kegiatan yang akan dicanangkan bersama. Hal tersebut diperkuat dari keterangan waka bidang kesiswaan madrasah yakni bapak Imam Mursyid, mengenai program aktifitas kesiswaan.beliau mengatakan bahwa, "semua rencana program terkait kesiswaan yang akan dijalankan kedepanya dibicarakan bersama oleh kepala madrasah para dewan pendidik serta parwakilan peserta didik yakni osis dan pradana untuk mengungkapkan pendapatnya masing masing”. Hal yang sama juga diungkapkan oleh bapak Ali fauzi selaku operator madrasah beliau mengatakan bahwa "supaya rencana program dapat berjalan dengan baik seperti yang direncanakan dan diharapkan, semua perangkat madrasah yang ada diikutkan pada rapat pencangan program tersebut agar semuanya tahu”. Keterangan yan sama juga diungkapkan oleh perwakilan peserta didik yakni diwakili oleh saudara Lucky Firmansyah selaku ketua osis yang besangkutan mengatakan bahwa, "Kegiatan yang akan kami kerjakan yang berhubungan dengan para peserta didik, kami ikut dalam perencanaan program tersebut dan dalam program tersebut diikuti oleh semua bapak ibu pendidik dan bapak kepala madrasah sebagai pemimpin rapatnya".dan program yang dibahas adalah mengenai program program yang berhubungan dengan kesiswaan.

Kegiatan meningkatkan belajar mengajar sudah dicanangkan pada awal tahun. Seperti contoh, bagi kelas dua belasakan diberikan tambahan waktu belajar yakni kegiatan bimbel pada semester genap guna menghadapi ujian disemester genap atau akhir yakni ujian nasional. Kepala madrasah juga membuat program supervisi yang bertujuan untuk meningkatkan profesionalitas dewan pendidik yang berdampak pada meningkatnya hasil prestasi belajar para peserta didik.

Program supervisi adalah program yang menjadi tugas pokok dan fungsi kepala madrasah sebagai seorang penyelia.Supervisi memiliki tujuan membimbing para dewan pendidik untuk meningkatakan profesionalitasnya.

Berhubungan dengan program pencanangan program supervsi akademik madrasah, kepala madrasah bekerjasama dengan para dewan pendidik yang memiliki tujuan untuk memberikan arahan bimbingan terhadap para pendidik.Kepala madrasah mengadakan pertemuan rapat yang bernuansa keharmonisan agar tercipta nuansa kerjasama yang baik antara kepala madrasah dengan dewan pendidik. Karena kepala madrasah disini ialah seorang supervisor dan supervisor menurut teori yang ada, 1) supervisor haruslah ramah, mudah didekati dan fleksibel serta berpengetahuan ilmu luas dan banyak akal 2) mampu menjalin hubungan yang baik dan profesional dengan pendidik lebih lebih kepada para peserta didik yang ada ditempat dia mengabdi, serta mampu mendukung dan membimbing selama proses penelitian ${ }^{14}$. Kepala madrasah dengan dewan pendidik saling bertukar pendapat mengenai aktifitas perencanaan program supervisi kedepanya.

Dari hasil wawancara intens bersama waka bidang kurikulum yakni ibu Chamidah selaku waka kurikulum madrasah menyatakan bahwasanya "program supervisi merupakan bantuan yang diberikan terhadap para dewan pendidik setelah

${ }^{14}$ Izah Mohd Tahir et al., "Effective Supervision from Research Students' Perspective," International Journal of Education 4, no. 2 (2012): 211, https://doi.org/10.5296/ije.v4i2.1531, h. 221. 
kepala madrasa h melaksanakan identifikasi masalah yang terjadi di madrasah". Hal yang sama diutarakan oleh beliau bapak operator tata usaha madrasah yakni bapak Ali Fauzi selaku staff operator tata usaha mengatakan bahwa, "kepala madrasah mengajak staffnya untuk membantunya dalam mengecek masalah yang ada. berdasarkan temuan identifikasi yang didapat bahwa kinerja para dewan pendidik masih dikatakan rendah yang paling penting yakni didalam penyusunan rancangan perangkat pembelajarandan pemilihan metode atau strategi pengajaran yang mengena pada peserta didik". Oleh karenanya, kepala madrasah menginstruksikan agar diadakanya musyawarah mengenai program perencanaan supervisi.

Berdasarkan data tersebut didapati bahwa pada pencanangan kepala madrasah melaksanakan rapat bersama semua pendidik guna mencanangkan program supervisi.Hal ini sesuai dengan prinsip supervisi pendidikan yang dikemukakan E.Mulyasa, yakni kepala madrasah menciptakan nuansa keharmonisan dengan pendidik, sehingga terjadi hubungan kerjasama yang bersifat keakraban.Dengan kondisi tersebut maka diharapkan para dewan pendidik bisa menyampaikan dengan pengutaraan masalahnya secara terbuka. ${ }^{15}$

Berdasarkanteori E.Mulyasa, ada konsep lain yang menjelaskan mengenai karakteristik pencanangan supervisi yaitu hendaknyabersifat koperatif, yangmaksutnya pelaksanaan supervisi yang dilakukan nanti memerlukan bantuan dari orang lain, sehingga didalam perencanaanpun diperlukan peran bantuan masukan dari orang orang yang berhubungan dalam kegiatan pelaksananya. ${ }^{16}$

Kepala madrasah sudah membuat agenda penjadwalan program mengenai kegiatan supervisi dalam agenda kerjanya.Berdasarkan hasil dari wawancara intens bersama kepala madrasah, didapati bahwasanya program supervisi diagendakan dua kali sesi pertemuan dalam jangka satu tahun sekali.Ini bertujuan supaya dewan pendidik senantisa terus membenahi dan mengevaluasi kelemahan dan kekurangan yang dimilikinya mengenai kegiatan pengajaran yang dilakukan maupun dalam kelengkapan admisnistrasi pembelajaran yang hendaknya dilengkapi.

Berkaitan dengan pencananganya program supervisi pendidikan, kepala madrasah dengan pertimbanganya, dan menimbang terdapat beberapa point hal penting didalamnya yakni mengenai sasaran dari supervisi, ruang lingkup dari supervisi, tujuan dari supervisi, indikator keberhasilan dari supervisi, strategi/metode kerja supervisi, kegiatan supervisi, penilaian supervisi dan instrumen dari supervisi, rencana tindak lanjut dari supervisi, waktu dari pelaksanaan supervisi. Dari beberapa point komponen diatas merupakan materi rujukan dari penyusunan program.Hal ini menunjukan dari kepala madrasah terkait pembuatan program.

Dalam program supervisi pendidikan terdapat sembilan point penting yang hendaknya dilakukan yakni yang pertama ialah sasaran supervisi. Dalam supervisi, sasaran yang dimaksut ialah dewan pendidik Madrasah Aliyah.Tujuanya adalah untuk meningkatkan kemampuan para pendidik supaya bisa tepat terhadap tujuan yang dituju.

\footnotetext{
${ }^{15}$ Mulyasa, Manejemen \& Kepemimpinan Kepala Sekolah, h. 252.

${ }^{16}$ Abdul Kadim Masaong, Supervisi Pembelajaran Dan Pengembangan Kapasitas Guru, h. 80.
} 
Point yang selanjutnya yakni yang kedua ialah ruang lingkup supervisi mengenai pemantauan proses belajar mengajar yang dimulai dari tahapan pencanangan, pelaksanaan, dan penilaian dari hasil proses pembelajaran. Program supervisi yang telah dilakukan memiliki tujuan agar kinerja dari para pendidik lebih terpantau, tentunya itu semua berkaitan dengan tahap dari pencanangan, pelaksanaan dan evaluasi pembelajaran. Dengan itu kepala madrasah sebagai seorang pemimpin dan supervisor bisa melihat dan menemukan kekurangan dan kelebihan dari para pendidik dalam proses mengajar.

Point yang ketiga yaitu mengenai tujuan supervisi antara lain ialah menyediakan feedback yang bersifat obyektif terhadap dewan pendidik, terkait pengajaran yang dilakukan, memeriksa dan membantu pendidik dalam pemecahan problem dalam aktifitas pengajaran, serta membantu pendidik untuk senantiasa mengembangakan kemampuan yang dimilikinya dalam metode pengajaran, serta dapat memberikan bantuan terhadap pemikiran positif yang berorintasi terhadap pengembangan profesional yang berkesinambungan.

Dari data tersebut dapat dilihat bahwa tujuan program supervisi adalah membantu dewan pendidik untuk mengembangkan keterampilan mengajarnya, hal tersebut sesuai dengan tujuan supervisi yang dijelaskan oleh Sahertian didalam bukunya yakni "supervisi pendidikan". Tujuan dilakukanya supervisi sendiri ialah :

1. Memberikan bantuan pada para pendidik dalam penyusunan persiapan mengajarnya.

2. Memberikan bantuan pada pendidik dalam melaksanakan proses kegiatan belajar mengajarnya.

3. Memberikan bantuan pada pendidik terkait pengunaan sumber belajar yang didapat dan media pembelajaran yang digunakan.

4. Memberikan bantuan pada pendidik didalam mengimplementasikan teknik mengajarnya.

5. Memberikan bantuan pada pendidik didalam melakukan evaluasi dalam pembelajaran yang telah dilakukan.

6. Memberikan bantuan pada para pendidik didalam menganalisis hasil belajar mengajar yang telah dilakukan.

7. Memberikan bantuan pada para pendidik didalam menganalisis kesulitan belajar yang dimilki para peserta didik. ${ }^{17}$

Berdasarkan penjelasan tersebut di peroleh bahwa tujuan dari program supervisi pendidikan yang disusun oleh kepala madrasah sesuai dengan teori yang mengatakan tentang tujuan dari supervisi.

Point yang selanjutnya yakni yang keempat ialah dewan pendidik mampu merencanakan pembelajaran, melaksanakan pembelajaran , menilai hasil pembelajaran peserta didik dan memanfaatkan hasil penilaian tersebut guna meningkatkan pelayanan pembelajaran, membuat lingkungan belajar yang lebih kondusif, menggunakan sumber belajar yan tersedia, mengembangkan interaksi mengenai pembelajaran sesuai dengan karakteristik. Indikator tersebut merupakan

\footnotetext{
${ }^{17}$ Piet A. Sahertian, Supervisi Pendidikan, (Jakarta : Rineka Cipta, 1992), h. 85.
} 
ukuran kesuksesan program supervisi akademik.Jika pendidik telah memenuhi kriteria diatas maka aktifitas supervisi sudah berhasil.

Point yang selanjutnya yakni yang kelima ialah mengenai strategi supervisi yang digunakan yakni menggunakan metode supervisi klinis, pembinaan, penilaian, dan pemantauan secara berkesinambungan.Supervisi pembinaan dan penilaian dengan menggunakan instrument supervisi akademik, standar proes, monitoring dan evaluasi/pemantauan guna mengetahui tingkat pencapaian progam yang sudah dicanangkan.

Dari penjelasan tersebut dapat diketahui bahwa kepala madarasah sudah membuat skenario kegiatan supervisi sesuai dengan pendapat tentang pelaksanaan supervsisi akademik pendidik.

Point penting yang selanjutnya yakni yang ketuju ialah penilaian dan instrument yakni penilain sendiri sudah termasuki kedalam supervisi dan instrument (terlampir) instrument supervisi standar proses dan standar penilaian.

Pointpenting selanjutnya yakni yang kedelapan ialah rencana evaluasi tindak lanjut setiap diakhir pembelajaran mengadakan evaluasi pelaksanaan program guna menindak lanjuti penyusunan program pada tahun depan dan kepala madrasah menjelaskan hasil dari pengawasan evaluasi dan supervisi sebagai refleksi serta menjadi acuan ditahun tahun berikutnya.

Point penting yang selanjutnya yakni yang kesembilan yaitu waktu pelaksanaan.Program supervisi dicanangkan pada bulan juli sampai minggu awal desember.

Kepala madrasah perlu menguasai mengenai perencanaan supervisi akademik sehingga ia perlu menguasai kompetensi perecanaan supervisi akademik dengan baik. Terdapat sejumlah prinsip yang perlu diperhatikan dalam perencanaan supervisi akademik, yaitu meyangkut :

a) Objektif

b) Tanggung Jawab, yang terus menerus

c) Berdasar dari standar nasional pendidikan

d) Berdasar dari kebutuhan yang dibutuhkan madrasah dan kondisi yang dialami madrasah. ${ }^{18}$

Berdasarkan yang terdapat dilapangan dapat diketahui bahwa kepala madrasah dalam pencangan supervisi sudah memenuhi dari beberapa prinsip yang ada. Prinsip yang awal hendaknya adalah objektif, didalam pencanangan kepala madrasah mementingkan suatu objektifitas, ini berarti dalam menentukan sasaran yang akan dituju dalam supervisi. Kepala madrasah melihatnya secara objektif bukan dengan subjektif

Prinsip yang nomor dua yaitu bertanggung jawab dan terus menerus dilakukan, dari pencanangankegiatan supervisi didapati bahwasanya skenario kegiatanya adalah pemberian bimbingan terhadap para pendidik, melaksanakan kunjungan ke kelas dan mengevaluasi serta menindak lanjutiya. Ini tentunya membuktikan bahwasanya kegiatan supervisi yang diprogramkan bersifat terus

${ }^{18}$ Priansa, Manajemen Supervisi \& Kepemimpinan Kepala Sekolah, h. 122. 
menerus dilakukan atau dengan pengertian lain kepala madrasah bertanggung jawab terhadap upaya peningkatan kualitas kinerja pengajaran para pendidik yang ada.

Prinsip yang selanjutnya ialah berdasar dari standar nasional dalam pendidikan. Dari aktifitas program supervisi Madrash Aliyah Walisongo didapati bahwa ada indikator pencapaianya yaknipendidik mampu membuat pencanangan, pelaksanaan dan pengevaluasian pembelajaran dengan baik. Hal tersebut tentunya mengacu pada komponen standar isi , dan proses yang ada yang telah ditentukan.

Prinsip selanjutnya, ialah berdasarkan pada kebutuhan yang dibutuhkan madrasah dan kondisi yang dialami madrasah yang ada. Berdasarkan temuan yang diperoleh bahwasanya sebelum membuat program kepala madrasah sudah mengetahui problem yang ada yang dialami dan dibutuhkan dan yang sudah terjadi di madrasah, maka dari itu kepala madrasah membuat agenda kegiatan supervisi pendidikan. Maka hal tersebut berarti sudah memenuhi syarat prinsip yang nomor keempat yakni berdasarkan atas kebutuhan madrasah yang dibutuhkan dan kondisi yang dialami madrasah.

Berdasarkan keterangan tersebut bisa diambil benang merah bahwasanya kepala madrasah sudah memenuhi syarat mengenai pencanangan supervisi.Didalam kegiatan pencanangan supervisinya, kepala madrasah sudah menyusun jadual kunjungan ke kelas, membuat instrument instrument supervisi dan perlengkapan lain lainya. Dalam pencanangan program aktivitas supervisinya terdiri dari kegiatan monitoring, bimbingan, dan evaluasi yang diselaraskan dengan prosedur aturan yang ditentukan program supervisi yang dilaksanakan melalui supervisi dalam kondisi kondisi tertentu didalam madrasah selain supervisi kelas, ada supervsi yang dilakukan juga pada kegiatan extrakurikuler, dan juga supervisi yang dilakukan pada perpustakaan, pada laboratorium dan ujian. Sampai saat ini yang bisa dilakukan adalah supervisi kelas.

Peran kepala madrasah sebagai seorang pengawas, berarti kepala madrasah adalah sosok yang bertugas membimbing dan memberikan pelayanan kepada para pendidik dan peserta didik di madrasah.Dari hasil wawancara intens peneliti bersama beberapa pendidik di ruangan pendidik.Diketahui data berkenaan supervisi yang dilaksanakan kepala madrasah biasanya disampaikan dulu. Kepala madrasah berencana mengadakan musyawarah rapat bersama para pendidik dan menyampaikanya, guna menyiapkan segala administrasi berkas berkas terkait dengan aktifitas supervisi yang dilaksanakan, karena biasanya program supervisi kepala madrasah akan melanjutkan dengan supervisi secara terpadu yang akan dilaksanakan dan dibimbing oleh pengawas dari pendidikan dinas kemenag kabupaten.

Dari wawancara bersama kepala madrasah, didapati bahwa selain program supervisi pendidikan, kepala madrasah juga sudah menyusun jadwal yang dibuat selaras dengan kebutuhan para dewan pendidik yang dibutuhkan.

Hal tersebut juga disampaikan kebenaranya oleh bapak Miftahul Amin dalam proses penyusunan jadual kunjungan ke kelas, kepala madrasah meminta saran dari para dewan pendidik yang sudah pengalaman. Guna menentukan siapa saja yang akan diutus, biasanya yang diutus adalah pendidik yang telah mendapatkan sertifikasi pendidik yang akan di siapkan dalamkegiatan supervisi pada bulan 
pertama,pada bulan kedua dan bulan ketiga serta selanjutnya. "Kepala madrasah menginfokan kepada dewan pendidik bahwa siapa sajakah yang sudah siap untuk dilakukan supervisi pada bulan pertama dan selanjutnya”.Pernyataan yang sama juga disampaikan oleh ibu Elie bahwasanya " sebelum kepala madrasah menentukan jadual supervisi beliau meminta pendapat dari dewan pendidik terlebih dahulu siapakah yang siap pada bulan ini dan siapakah yang siap pada bulan selanjutnya”. Dengan seperti itu para pendidik akan mempersiapkan segala sesuatunya supaya lebih matang.

\section{Pelaksanaan Program Supervisi Akademik}

Kegiatan pelaksanaan supervisi akademik merupakan langakah lanjutan dari pencanangan kegiatan supervisi.Kepala madrasah sebagai seorang supervisor mengimplementasikan kegitan dari rencana program supervisi akademik yang dibuat.Dalam prakteknya dari program tersebut, kepala sekolah mengagendakan aktifitas pemberian bimbingan didalam pembuatan perangkat pembelajaran, melaksanakan kunjugan kelas dan memberikan evaluasi dari hasil dari supervisi yang dilaksanakan.

Berdasarkan kegiatan wawancara bersama kepala madrasah, diketahui bahwa kepala madrasah sudah melakukan pemberian bimbingan terhadap penyusunan perangkat silabus yang berkaitan dengan standar isi serta kurikulum yang ditentukan. Kepala madrasah mengungkapkan bahwa "perangkat silabus ialah rujukan awal dari pembuatan rencana didalam perangkat pembelajaran yang bersandar pada standar isi serta kurikulum yang ditentukan, maka dari itu para pendidik harus sebisa mungkin diberikan bimbingan dan bantuan intens disaat proses penyusunanya".

Pernyataan tersebut tidak sesuai dengan bukti yang ada, karena tidak ditemukanya dokumen terkait hal itu yang menjadi penguat pernyataan bahwa kepala madrasah sudah membimbing dalam penyusunan perangkat silabus pengajaran. Itu semua juga diperkuat oleh pernyataan yang diungkapkan oleh Bapak Khoiril Anam beliau menyatakan bahwa, " bapak kepala madrasah tidak memberikan bimbingan penyusunan silabus secara intens hanya sekedar diberi penjelasan setelah itu disuruh saja membuat dan para pendidik berusaha belajar sendiri atau meminta ajari kepada dewan pendidik yang sudah bisa”. pernyataan yang sama disampaikan oleh bapak Miftahul Amin, beliau mengungkapakan bahwa "kepala madrasah tidak membimbing dalam pembuatan silabus. Kebanyakan pendidik hanya mencari dari google dan mendownloadnya setelah itu diedit lagi dan sebagian pendidik belajar dari tutorial di youtube".

Berdasarkan kacamata teoritis kepala madrasah adalah seorang sosok pemimpin dan pengawas madrasah yang salah satu tugasnya adalah membimbing dan melakukan pengawasan terhadap para dewan pendidik dalam kegiatan pengajaran. Supervisi yang telah dilaksanakan menggunkan metode kunjungan kelas.Didalam pelaksananya, kepala madrasah mempunyai peran sebagai seorang penyelia bimbingan pada pendidik dalam pembuatan perangkat pengajaran.

Dari identifikasi yang diperoleh peneliti terkait pelaksanaan supervisi pendidikan, kepala madrasah tidak memberikan bantuan professional berupa 
bimbingan.Penyusunan perangkat pembelajaran. Hal tersebut diperoleh dari hasil wawancara terhadap pendidik bidang study matematika yakni Bapak Khoiril Anam. Beliau mengungkapkan bahwa,"kepala madrasah kurang lengkap dan mendetail didalam memberikan penjelasan terkait proses perencanan perangkat rencana pembelajaran. Kepala madrasah kurang sungguh sungguh dalam menjelaskan point point dalam perangkat rencana pembelajaran". Seperti contohnya sub pemilihan teknik dalam mengajar tidak dijelaskan secara lengkap sehingga beberapa dewan pendidik masih merasa sulit dalam memilih strategi atau tehnik seperti apa yang akan digunakan.

Pernyataan yang senada juga di katakan oleh dewan pendidik bidang study sosilogi, yakni bapak Miftahul Amin beliau mengutarakan bahwa, "dalam penyusunan rencana perangkat pembelajaran dibutuhkan sekali kemampuan yang berhubungan dengan IT yakni kemampuan mengoprasikan komputer dan menjalankan aplikasi microsoft word dan microsoft excel namun dari beberapa dewan pendidik tidak mempunyai kemampuan tersebut dikarenakan sudah sepuh karena penyusunanya bukan manual lagi yakni tulis tangan tetapi diketik dengan komputer". dari keterangan yang diberikan dewan pendidik tersebut juga diutarakan oleh operator tata usaha Madrasah Aliyah yakni bapak Ali Fauzi beliau menyatakan bahwa, "Pengetikan silabus dan rencana perangkat pembelajaran dan lain lain, saya malahan yang mengajari sebagian dewan pendidik mengetik". Sehingga dari keterangan keterangan tersebut, menunjukan bahwa, kepala madrasah kurang tlaten didalam meberikan bimbingan kepada pendidik yang masih kurang dalam kemampuan IT komputernya dalam menyusun perangkat pembelajaranya. Bahkan kepada beberapa pendidik tidak dibimbingdalam penyusunan rencana perangkat pembelajaranya.

Pelaksanaan supervisi merupakan kegiatan yang dalam prakteknya hendaknya dilakukan dengan baik, maka dari itu dibutuhkan metode yang baik pula dalam proses pelaksanaanya. Ada beberapa metode didalam kegiatan supervisi, yaitu metode yang bersifat individual dan metode yang bersifat kelompok.

Dari temuan yang diperoleh, bahwa dalam pelaksaan supervisi di Madrasah Aliyah adalah yang bersifat individual dan menggunakan tehnik kunjungan ke kelas kelas. Kunjungan ke ruangan kelas yang dilakukan kepala madrasah memiliki tujuan untuk mengetahui langsung kelemahan kerja pendidik sehingga akan menjadikan bahan didalam perbaikan. Tehnik kunjungan ke ruangan kelas diadakan dua kali didalam satu tahun, supaya para dewan pendidik lebih bisa menyiapakan segala sesuatu yang berkaitan dengan perangkat pembelajaran serta selalu memperbaiki kemampuan dalam mengajar.

Temuan tersebut bertolak belakang dengan penjelasan konsep supervisi pendidikan yang memukakan bahwa metode terbagi menjadi dua yakni metode individual dan kelompok. Metode yang bersifat individual meliputi: kunjunngan ke kelas, observasi kelas, percakapan dengan secara pribadi, intervisitasi, menyeleksi macam macam sumber dalam belajar mengajar, menilai diri sendiri. Tehnik yang bersifat kelompok yakni pertemuan orientasi, rapat musyawarah pendidik, belajar secara berkelompok antar dewan pendidik, diskusi bersama, bertukar pengalaman, 
webminar dan lain lain. ${ }^{19}$ Sehingga, dapat diambil kesimpulan bahwa kepala madrasah kurang kretaif inovatif didalam memilih metode yang akan digunakan mensupervisi dewan pendidik.

Dalam mewujudkan peningkatan kinerja para pendidik, kepala madrasah melaksanakan supervisi terhadap para pendidik untuk memberikan usaha pembenahan dalam pengajaran.Didalam melaksanakan kegiatan supervisi ada dua tehnik yaitu tehnik yang bersifat individual dan bersifat kelompok. Berdasarkan observasi di sana, kepala madrasah menggunakan teknik yang bersifat individual yakni kunjungan ke ruangan kelas, hal yang dilakukan kepala madrasah ialah melakukan pengidentifikasian terhadap perangkat perangkat pengajaran seperti kelengkapan rencana perangkat pembelajaran, beserta perangkat lainya. Kepala madrasah melakukan observasi langsung terhadap para dewan pendidik sebelum dimulainya kegiatan pembelajaran, melaksanakan kegiatan pembelajaran sampai evaluasi kegiatan pembelajaran.Sebelum kepala madrasah masuk ke kelas, kepala madrasah sudah menyiapkan catatan singkat yang penting berkaitan dengan kekurangan yang dimiliki pendidik yang bersangkutan.

Berdasarkan analisis data tersebut bisa diambil benang merah bahwa sanya kepala madrasah sudah melaksanakan amanahnya sebagai seorang pimpinan dan sebagai supervisor yang baik dengan membuat program perencanaan sebelumnya, program pelaksanaan yang telah dilakukan dalam kegiatan supervisi tetapi hanya saja masih kurang pada kegiatan evaluasii atau tindak lanjut dari supervisinya saja yang sama sekali belum dilakukan. Berdasarkan paragraph tersebut yang pada intinya menjelaskan bahwa kepala madrasah sudah bertanggung jawab menjalankan sebisanya amanahnya sebagai seorang pimpinan hanya saja perlu masih banyak evaluasi perbaiakan mendalam terhadap program yang dilakukan.

\section{Simpulan}

Penerapan supervisi akademik kepala madrasah di dalam tahapan perencanaan sudah cukup baik. Hanya saja di dalam kegiatan pelaksanaanya maupun evaluasinya atau tindak lanjutnya belum dilakukan dengan baik dan maksimal. Maka dari itu, hendaknya ada kegiatan yang menuju kearah peningkatan dalam penerapan supervisi akademik kepala madrasahnya. Serta kinerja pengajaran bagi para pendidik hendaknya senantiasa di tingkatkan terus, yang dilakukan dengan terus berangsur angsur baik dalam perencanaan, pelaksanaan dan evaluasinya. Kepala madrasah hendaknya mempunyai pedoman diri yang kuat didalam menentukan segala keputusan dalam menghadapai permasalahan terkait pendidik guna memperbaiki kinerja dari pendidik supaya terjadi peningkatan. Kepala madrasah hendaknya lebih pilih pilih atau selektif dalam merekrut para dewan pendidik baru yang akan dipekerjakan. Dan pada seluruh komponen organisasi yang ada di madrasah baik itu staff karyawan dan para dewan pendidik bersama kepala madrasah hendaknya senantiasa bersama sama meningkatkan mutu madrasah agar tercapainya tujuan pendidikan yang telah di cita citakan bersama.

\footnotetext{
${ }^{19}$ Donni Junni Priansa, Manajemen Supervisi \& Kepemimpinan Kepala Madrasah, (Bandung Alfabeta) h.99.
} 


\section{DAFTAR PUSTAKA}

Abdul Kadim Masaong, Supervisi Pembelajaran Dan Pengembangan Kapasitas Guru, (Bandung: Alfabeta, 2010).

Direktorat Tenaga Kependidikan Direktorat Jenderal Penjamin Mutu Pendidikan dan Tenaga Kependidikan Departemen Pendidikan Nasional Tim Penulis, Metode Dan Tehnik Supervisi (Jakarta: Diknas, 2008).

Donni Junni Priansa, Manajemen Supervisi E Kepemimpinan Kepala Madrasah, (Bandung Alfabeta)

E. Mulyasa, Menjadi Kepala Sekolah Profesional (Bandung: Remaja Rosdakarya, 2005).

H Makawimang Jerry, Supervisi Klinis : Teori \& Pengukuranya (Bandung: Alfabeta, 2012).

Hadari Nawawi, Administrasi Pendidikan (Jakarta: CV Haji Mas Agung, 1998).

Izah Mohd Tahir et al., "Effective Supervision from Research Students' Perspective," International Journal of Education 4, no. 2 (2012): 211, https://doi.org/10.5296/ije.v4i2.1531.

Jerry H Makawimang, Supervisi Klinis (Teori E Pengukuranya) (Bandung: Alfabeta, 2013).

Komari, Kepala Madrasah Aliyah Walisongo Umbul Madiun, Wawancara, Tanggal 2 Februari 2019.

Maryono, Dasar Dasar Tehnik Menjadi Supervisi Pendidikan, h. 23.

Pascasarjana Program, Ar-Raniry Uin, And Aceh Banda, "Implementasi Supervisi Pendidikan Dalam Meningkatkan Proses Pembelajaran Di Min Sukadamai Kota Banda Aceh Cut Suryani," Jurnal Ilmiah Didaktika Agustus, Vol. 16, 2015. Piet A. Sahertian, Supervisi Pendidikan, (Jakarta : Rineka Cipta, 1992), h. 85.

Priansa, Manajemen Supervisi \& Kepemimpinan Kepala Sekolah, (Bandung: Alfabeta, 2014).

Sahertian, Konsep Dasar Dan Tehnik Supervisi Pendidikan Dalam Rangka Mengembangkan SDM, (Jakarta: Rineka Cipta, 2010).

Saqib Khan et al., "The Supervisory Role of the The Supervisory Role of the Headmaster at the Higher Secondary Level: A Teacher's Perception," Public Policy and Administration Research 4, no. 9 (2014): 51-55.

Suhardan, Supervisi Profesional, (Bandung : Alfabeta). 